\title{
EFFECTS OF DIFFERENT GLAZE TREATMENTS ON THE OPTICAL PROPERTIES AND ROUGHNESS OF LITHIUM DISILICATE CERAMICS
}

\begin{abstract}
Objectives: To investigate effects of different glaze procedures on the colour, translucency, and roughness of lithium disilicate (LDS) ceramics after short-term ageing.
\end{abstract}

Materials and Methods: Eighteen LDS specimens (thickness: $0.6 \mathrm{~mm}$ ) were divided into three groups (paste (EP), spray (ES), and powder-liquid glaze (EL)) based on the type of glaze treatment $(n=6)$. After glaze firings, specimens were thermally aged (5000 cycles). Before and after thermocycling, the colour, translucency, and roughness values of the specimens were measured. Before and after thermocycling, the translucency and roughness data were analysed using a one-way analysis of variance (ANOVA) and compared using a Wilcoxon signedrank test. Changes in colour, translucency, and roughness data were analysed using one-way ANOVA, and the correlations between them were analysed using Spearman's correlation analysis $(\mathrm{p}=.05)$.

Results: The EL group showed the highest and clinically unacceptable colour change value $(\mathrm{p} \leq .005)$. Before and after ageing, the EL group exhibited higher translucency than the other groups $(p<.001)$, and the EL and EP groups exhibited higher roughness values than the ES group $(\mathrm{p} \leq .001)$. Wilcoxon signed-rank test results showed that although a significant difference between the initial and final translucency values was observed in the EL group ( $p=.028)$, no significant differences between the initial and final roughness values were observed in each group. Only in the EL group, a significant correlation was found between the colour and translucency change values $(\mathrm{r}=.943, \mathrm{p}=.005)$.

Conclusions: After short-term ageing, based on the evaluation of the LDS ceramics' colour and translucency changes, ES and EP treatments are preferable for glazing. When dentists select a material (EP, EL, ES) for glazing LDS ceramics, they should consider the effects of this material on the optical properties and surface roughness of LDS ceramics.

Keywords: Lithia disilicatex, color, surface properties
*Gülce M. Subaş $1^{1}$, (iD Gülce $\mathrm{Alp}^{2}$

ORCID IDs of the authors:

G.M.S.0000-0002-2510-9745

G.A.0000-0003-1751-9207

\footnotetext{
${ }^{1}$ Department of Prosthetic Dentistry, Faculty of Dentistry, Kütahya Sağlık Bilimleri University, Kütahya, Turkey.

${ }^{2}$ Department of Prosthetic Dentistry, Faculty of Dentistry, İstanbul Okan University, İstanbul Turkey.
}

$\begin{array}{ll}\text { Received } & : 25.12 .2018 \\ \text { Accepted } & : 11.02 .2019\end{array}$

How to Cite: Subaşı GM, Alp G Effects of Different Glaze Treatments on The Optical Properties and Roughness of Lithium Disilicate Ceramics Cumhuriyet Dent J 2019;22:1:48-55. 


\section{INTRODUCTION}

In prosthetic dentistry, the advent of computeraided design (CAD) and computer-aided manufacturing (CAM) has facilitated the design of frameworks, monolithic crowns, and fixed dental prostheses. CAD/CAM restorations exhibit acceptable shade, contour, and marginal adaptation compared with conventionally fabricated restorations. ${ }^{1,2}$

Achieving a natural tooth-like restoration is important for a successful treatment. ${ }^{3}$ To attain optimum aesthetic results, the optical properties of the restoration must match those of natural teeth. ${ }^{4}$ For this purpose, in recent years, numerous CAD/CAM-machinable ceramic materials have been developed. The choice of ceramic materials is based on their mechanical and optical properties. ${ }^{3}$ Glass ceramics are often used in chairside CAD/CAM dental treatments. ${ }^{5}$ Among glass ceramics, the lithium disilicate (LDS) glass ceramic (IPS e.max CAD) has better optical and mechanical properties than conventional dental ceramics. This ceramic can be used for three-unit fixed dental prostheses up to the first premolar and for single-unit crowns, inlays, and onlays. ${ }^{6}$ In recent years, because of the various translucency levels and shades exhibited by LDS ceramics, they have been widely used for monolithic ceramic restorations. ${ }^{3,6,7}$

The translucency of a dental ceramic is a primary factor influencing the overall aesthetics. ${ }^{89}$ Colour stability throughout the functional lifetime of a restoration is as crucial as mechanical properties of the material. A change in colour over time may limit the longevity and quality of a restoration. ${ }^{10}$ Extrinsic factors, such as the type of solution, exposure time ${ }^{11}$, firing time ${ }^{12}$, glaze used $^{13}$, surface texture ${ }^{14}$, surface treatment ${ }^{15}$, and colour combination among the substrate/ ceramic/cement ${ }^{16}$, and intrinsic factors, such as material composition ${ }^{11,15}$ and crystal particle size $^{17}$, are important factors influencing the colour stainability of ceramic restorations.

Ceramic restorations must have smooth surfaces to yield patient comfort, attain aesthetics and to perform excellent biological and mechanical properties. A coarse surface may ease staining, enhance plaque accumulation, cause abrasion and wear of antagonistic teeth, and ultimately affect the fracture strength of the ceramic. ${ }^{18}$ Therefore, glazing of restorations is mandatory before cementing them. ${ }^{19,20}$

Various parameters affecting LDS ceramics have been investigated ${ }^{20-27}$, including the effects of roughness ${ }^{20,26}$ and thickness on their translucency. ${ }^{21-}$ ${ }^{23}$ Yuan et al..$^{27}$ evaluated the effects of brushing and thermocycling on colour stability and roughness of glazed CAD/CAM ceramic restorations (LDS and zirconia). Other studies evaluated the effects of thermocycling and thickness either on the colour stability $^{25}$ or on both the colour stability and translucency of LDS ceramics. ${ }^{24}$

According to the instructions given by the manufacturer of the materials used, three methods for glazing monolithic LDS restorations have been recommended: paste, spray, and powder-liquid glaze. Although the manufacturer recommends each of the three glazing methods, studies on the effects of these procedures on optical properties and roughness of LDS ceramics are lacking. The aim of this study was to assess effects of different glazing procedures on the colour, translucency, and roughness of LDS restorations after short-term ageing.

The following are the research hypotheses:

1. The type of surface glazing treatment does not affect the colour change data.

2. Before and after ageing, the type of glazing treatment does not affect the translucency data.

3. Before and after ageing, the type of glazing treatment does not affect the roughness data.

\section{MATERIALS AND METHODS}

Table 1 lists the materials used in this research. Eighteen LDS specimens $(12.4 \mathrm{~mm} \times 14.5 \mathrm{~mm} \times$ $0.6 \mathrm{~mm}$ ) (IPS e.max CAD, Ivoclar Vivadent AG, Schaan, Liechtenstein) (A3/HT) were sectioned using a low-speed sectioning device (Secotom 10, Struers A/S, Ballerup, Denmark) under water cooling. The specimens were ultrasonically cleaned (Sultan 600 ProSonic 600-MTH, Mexico) for $10 \mathrm{~min}$ and air-dried before taking the 
roughness and colour measurements. They were then divided into three groups based on the glazing procedure $(n=6)$ : paste, spray, and powder-liquid glaze. All of the glazing applications and firing procedures were performed by the same operator.

Table 1. Materials used in this research.

\begin{tabular}{lccc}
\hline Material & Code & Manufacturer & Lot No \\
\hline IPS e.max CAD & LDS & Ivoclar Vivadent AG & V12245 \\
IPS e.max CAD Crystall./Glaze Paste & EP & Ivoclar Vivadent AG & T38546 \\
IPS e.max CAD Crystall./Glaze Spray & ES & Ivoclar Vivadent AG & W16246 \\
IPS e.max Ceram Glaze Powder & & Ivoclar Vivadent AG & U54478 \\
IPS e.max Ceram Glaze Liquid & EL & & U53409 \\
\hline
\end{tabular}

\section{Paste group $(E P)$ :}

Schaan, Liechtenstein) was applied on specimens In this group, a paste (IPS e.max CAD Crystall/Glaze Paste, Ivoclar Vivadent AG, using a brush. Crystallisation and glaze firings were then simultaneously performed (Table 2).

Table 2. Firing parameters for crystallisation/glaze HT with paste or spray or for only crystallisation.

\begin{tabular}{|c|c|c|c|c|c|c|c|c|c|c|c|}
\hline $\begin{array}{c}\mathrm{ST} \\
\left({ }^{\circ} \mathrm{C}\right)\end{array}$ & $\begin{array}{c}\mathrm{CT} \\
(\mathrm{min})\end{array}$ & $\begin{array}{c}\mathrm{HR} \\
\mathrm{t}_{1}\left({ }^{\circ} \mathrm{C}\right)\end{array}$ & $\begin{array}{c}\mathrm{FT} \\
\mathrm{T}_{1}\left({ }^{\circ} \mathrm{C}\right)\end{array}$ & $\begin{array}{c}\mathrm{HT} \\
\mathrm{H}_{1} \\
(\mathrm{~min})\end{array}$ & $\begin{array}{c}\mathrm{HR} \\
\mathrm{t}_{2}\left({ }^{\circ} \mathrm{C}\right)\end{array}$ & $\begin{array}{c}\mathrm{FT} \\
\mathrm{T}_{2}\left({ }^{\circ} \mathrm{C}\right)\end{array}$ & $\begin{array}{c}\mathrm{HT} \\
\mathrm{H}_{2} \\
(\mathrm{~min})\end{array}$ & $\begin{array}{c}\mathrm{V}_{1}\left({ }^{\circ} \mathrm{C}\right) \\
1_{1} / 1_{2}\end{array}$ & $\begin{array}{c}\mathrm{V}_{2}\left({ }^{\circ} \mathrm{C}\right) \\
21 / 2\end{array}$ & $\begin{array}{c}\mathrm{LTC} \\
\left({ }^{\circ} \mathrm{C}\right)\end{array}$ & $\begin{array}{c}\mathrm{CR} \\
\left({ }^{\circ} \mathrm{C}\right)\end{array}$ \\
\hline 403 & 6 & 90 & 820 & $0: 10$ & 30 & 840 & 7 & $550 / 820$ & $820 / 840$ & 700 & 0 \\
\hline
\end{tabular}

ST: Stand-by temperature; CT: Closing time; HR: Heating Rate; FT: Firing Temperature; HT: Holding Time; V: Vacuum; LTC: Long-term cooling; CR: Cooling rate.

\section{Spray group (ES):}

In this group, a spray (IPS e.max CAD Crystall/Glaze Spray, Ivoclar Vivadent AG, Schaan, Liechtenstein) was well shaken approximately $20 \mathrm{~s}$ before application. The spray can was held in an upright position, and the spray was applied on the specimen surface from a distance of $10 \mathrm{~mm}$. The crystallisation and glaze firings were performed simultaneously (Table 2).

\section{Powder-liquid glaze group (EL):}

In this group, the crystallisation firing (Table 2) was performed before glaze firing. Thereafter, powder and liquid glazes (IPS e.max Ceram Glaze Powder and Liquid, Ivoclar Vivadent AG, Schaan, Liechtenstein) were mixed homogenously in a plate and applied on the crystallised specimen surface using a brush. Finally, the glaze firing (Table 3) was conducted.

Table 3. Firing parameters for glaze firing.

\begin{tabular}{|c|c|c|c|c|c|c|}
\hline $\mathrm{ST}\left({ }^{\circ} \mathrm{C}\right)$ & $\mathrm{CT}(\min )$ & $\operatorname{HR}\left({ }^{\circ} \mathrm{C}\right)$ & $\mathrm{FT}\left({ }^{\circ} \mathrm{C}\right)$ & $\mathrm{HT}$ (min) & $\mathrm{V}_{1}\left({ }^{\circ} \mathrm{C}\right)$ & $\mathrm{V}_{2}\left({ }^{\circ} \mathrm{C}\right)$ \\
\hline 403 & 6 & 60 & 770 & $1-2$ & 450 & 769 \\
\hline
\end{tabular}

ST: Stand-by temperature; CT: Closing time; HR: Heating Rate; FT: Firing Temperature; HT: Holding Time; $\mathrm{V}_{1}$ : Vacuum 1; $\mathrm{V}_{2}$ : Vacuum 2.

In all the groups, the firings were performed in a furnace (Programat P300, Ivoclar Vivadent AG, Schaan, Liechtenstein) according to the instructions provided by the manufacturer. After glaze firing, the specimens were aged in a thermal cycling machine (Thermocycler THE 1100, SD Mechatronik, Westerham, Germany) (5000 cycles, 5-55 ${ }^{\circ} \mathrm{C}$, dwell time: $30 \mathrm{~s}$, transfer time: $10 \mathrm{~s}$ ).

\section{Colour Measurement}

The colour value of each specimen was measured using a chromometer (Minolta CR-321, Konica Minolta, Tokyo, Japan) both before and after thermocycling against a white backing. The $L, a$, and $b$ values, representing the lightness, red-green axis, and yellow-blue axis, respectively, were recorded. The CIELab (Commission 
Internationale de l'Eclairage) colour differences $(\Delta E)$ of each specimen were calculated using the CIELab formula. ${ }^{28}$

$\Delta \mathrm{E}=\left[\left(\mathrm{L}_{\mathrm{t}}-\mathrm{L}_{\mathrm{i}}\right)^{2}+\left(\mathrm{a}_{\mathrm{t}}-\mathrm{a}_{\mathrm{i}}\right)^{2}+\left(\mathrm{b}_{\mathrm{t}}-\mathrm{b}_{\mathrm{i}}\right)^{2}\right]^{1 / 2}$

where the subscripts $t$ and $i$ denote the final and initial values, respectively.

\section{Translucency Measurement}

For the translucency measurements, the colour value of each specimen was measured on black and white backings both before and after thermocycling.

The translucency parameter (TP) was calculated for each specimen both before and after thermocycling using the following equation: ${ }^{29,30}$

$\mathrm{TP}=\left[\left(\mathrm{L}_{\mathrm{b}}-\mathrm{L}_{\mathrm{w}}\right)^{2}+\left(\mathrm{a}_{\mathrm{b}}-\mathrm{a}_{\mathrm{w}}\right)^{2}+\left(\mathrm{b}_{\mathrm{b}}-\mathrm{b}_{\mathrm{w}}\right)^{2}\right]$ where the subscripts $b$ and $w$ denote the colour coordinates against black and white backings, respectively.

\section{Roughness}

The roughness values of specimens were measured using a profilometer (Perthometer M2, Mahr, Göttingen, Germany) (tracing length: 5.5 $\mathrm{mm}$, cut-off length: $0.8 \mathrm{~mm}$, and stylus speed: 1 $\mathrm{mm} / \mathrm{s}$ ). Three measurements were performed at the centre of each specimen, and the average of the measurements ( $\mathrm{Ra}$ in $\mu \mathrm{m}$ ) was considered for further analysis.

\section{Statistical Analysis}

The translucency and roughness data both before and after thermocycling were analysed using the one-way analysis of variance (ANOVA) and so were the colour, translucency, and roughness change data. For each group, the translucency and roughness data before and after thermocycling were compared using the Wilcoxon signed-rank test results. The correlations between the changes in the colour and translucency, colour and roughness, and translucency and roughness values were analysed using the Spearman's correlation analysis $(\mathrm{p}=.05)$.

\section{RESULTS}

Tables 4-6 list the statistical results of this study. The colour change data revealed that after thermocycling, the colour change values in the EL group were higher than those in the ES and EP groups ( $\mathrm{p} \leq$.005) (Table 4).

Table 4. Colour change values $(\Delta \mathrm{E})$ of different treatment groups.

\begin{tabular}{llll}
\hline & Mean & SD & p (one-way ANOVA) \\
\hline EL & $4.60^{\mathrm{b}}$ & 2.72 & .001 \\
ES & $0.72^{\mathrm{a}}$ & 0.33 & \\
EP & $1.10^{\mathrm{a}}$ & 0.53 & \\
* SD: Standard deviation. &
\end{tabular}

Both before and after thermocycling, the translucency values in the EL group were higher than those in the ES and EP groups $(p<.001)$. The Wilcoxon signed-rank test results showed a significant difference between initial and final translucency values $(p=.028)$ in EL group. The translucency change in EL group was significantly different from those in the other groups $(\mathrm{p} \leq .007)$ (Table 5).

Table 5. Translucency values of different treatment groups. 


\begin{tabular}{ccccc}
\hline & $\begin{array}{c}\text { Translucency } \\
\text { initial }\end{array}$ & Translucency final & $\begin{array}{c}\mathrm{p} \\
\text { (Wilcoxon signed- } \\
\text { rank test) }\end{array}$ & $\begin{array}{c}\text { Translucency change (final- } \\
\text { initial) }\end{array}$ \\
\hline Mean+SD & Mean+SD & & Mean+SD \\
\hline EL & $48.15+0.68^{\mathrm{b} 1}$ & $43.40+2.34^{\mathrm{b} 2}$ & .028 & $-4.75+2.72^{\mathrm{a}}$ \\
$\mathrm{ES}$ & $14.60+1.14^{\mathrm{a} 1}$ & $13.66+0.69^{\mathrm{a} 1}$ & .075 & $-0.93+1.15^{\mathrm{b}}$ \\
EP & $14.56+0.70^{\mathrm{a} 1}$ & $14.78+1.20^{\mathrm{a} 1}$ & .600 & $0.21+1.22^{\mathrm{b}}$ \\
\hline $\begin{array}{c}\text { p (one-way } \\
\text { ANOVA) }\end{array}$ & $<.001$ & $<.001$ & .001 \\
\hline * SD: Standard deviation. \\
** Divergent superscript letters in the same column and divergent superscript numbers in the same row show significant differences (p<.05).
\end{tabular}

Before and after thermocycling, the roughness values in the EL and EP groups were higher than that in the ES group $(\mathrm{p} \leq .001)$. The Wilcoxon signed-rank test results showed no significant differences between initial and final roughness values in each group. The one-way ANOVA test results showed no significant differences in the roughness change (final-initial) values in the different groups (Table 6).

Table 6. Roughness values ( $\mathrm{Ra}$ in micrometers) in different treatment groups.

\begin{tabular}{|c|c|c|c|c|}
\hline & $\begin{array}{c}\text { Initial roughness } \\
\text { Mean+SD } \\
\end{array}$ & $\begin{array}{c}\text { Final roughness } \\
\text { Mean }+\mathrm{SD} \\
\end{array}$ & $\begin{array}{l}\text { P (Wilcoxon signed-rank } \\
\text { test) }\end{array}$ & $\begin{array}{c}\text { Roughness change (final-initial) } \\
\text { Mean+SD }\end{array}$ \\
\hline EL & $0.65+0.11^{\mathrm{bl}}$ & $0.70+0.14^{\mathrm{b} 1}$ & .345 & $0.05+0.13^{\mathrm{a}}$ \\
\hline $\mathrm{ES}$ & $0.29+0.16^{\mathrm{a}}$ & $0.27+0.09^{\mathrm{a} 1}$ & .528 & $-0.02+0.09^{\mathrm{a}}$ \\
\hline EP & $0.67+0.10^{\mathrm{b} 1}$ & $0.71+0.11^{\mathrm{b} 1}$ & .398 & $0.03+0.08^{\mathrm{a}}$ \\
\hline $\begin{array}{c}P \text { (one-way } \\
\text { ANOVA) }\end{array}$ & $<.001$ & $<.001$ & & .635 \\
\hline
\end{tabular}

The Spearman's correlation analysis revealed that except for the EL group, the other groups did not exhibit any significant correlation between the changes in the colour and translucency, colour and roughness, and translucency and roughness values. In EL group, a significant correlation was found between the colour and translucency change data $(r=-.943$ and $p=.005)$.

\section{DISCUSSION}

The first null hypothesis, the type of surface glazing treatment does not affect the colour change data, was rejected $(\mathrm{p}=.001)$. This is because the colour change in the EL group was higher than those in the other groups $(\mathrm{p} \leq .005)$. Except for the EL group, the colour change values in the other groups are clinically acceptable $(\Delta \mathrm{E}<3.7)$.

The second null hypothesis, before and after ageing, the type of glazing treatment does not affect the translucency data $(\mathrm{p}<.001)$, was rejected. This is because, both before and after ageing, the translucency value in EL group was higher than those in other groups $(\mathrm{p}<.001)$
The third null hypothesis, before and after ageing, the type of glazing treatment does not affect the roughness data, was rejected $(\mathrm{p}<.001)$. This is because, before and after ageing, the roughness values in the EL and EP groups were higher than that in the ES group ( $\mathrm{p} \leq .001)$.

In a previous study ${ }^{27}$, the effects of brushing and thermocycling on colour stability and surface roughness of glazed LDS restorations were evaluated, and restorations were glazed using IPS e.max CAD Crystall/Glaze Paste. No correlation was found between colour change and surface roughness data. The colour change values of the LDS restorations were below the clinically perceptible threshold $(\Delta \mathrm{E}=2.6)$. Similarly, in our study, the EP group showed clinically acceptable colour change values after ageing, and no correlation was found between the roughness and colour change data.

Vichi et al. ${ }^{26}$ assessed the efficacy of finishing/polishing systems on the roughness and gloss of IPS e.max CAD treated using a glaze paste 
and a spray. They found that the glaze paste was more effective in reducing the roughness of the LDS restorations than the spray treatment. In our study, the roughness value in the ES group was lower than that in the EP group. Although the same material (paste and spray) was used in both studies, the difference may lie in the two-step firing approach employed by Vichi et al. ${ }^{26}$ We performed the crystallisation and glaze firings simultaneously for both glaze and paste treatments.

Subaş1 et al.$^{24}$ compared the effects of material and thickness on the colour stability and relative translucency parameters (RTP) of monolithic ceramics (lithium disilicate ceramic (LDS), zirconia reinforced lithium silicate ceramic (ZLS), and pre-shaded monolithic zirconia) subjected to coffee thermocycling (5000 cycles). They used a two-step firing approach and IPS e.max ceram for glazing the LDS ceramics. Staining in coffee did not affect the translucency of LDS ceramics. The colour change in LDS ceramics was similar with respect to the different thicknesses, and the changes were perceptible. However, in our study, the EL group showed clinically unacceptable colour change after thermocycling, which significantly decreased the translucency value in the EL group. The difference between the two results could be due to the use of different devices for colour measurement, different material thickness, and different formulae for colour change measurement.

In this study, the EL group showed the highest colour change and translucency values. The higher translucency could be due to the twostep firing procedure, and the higher colour change after thermal cycling could be due to the roughness of the material.

Previous studies ${ }^{19,20}$ reported that glaze treatment is preferred to surface polishing for LDS restorations. Based on these studies, ${ }^{26,27}$ the effects of different glazing treatments on the optical properties and roughness of an LDS material were investigated in this study. The thickness of the LDS material $(0.6 \mathrm{~mm})$ was kept constant when comparing the effects of different glazing treatments on its colour, translucency, and roughness values. Three different types of glazing procedure were investigated because these treatments were suggested from the manufacturer for glazing monolithic LDS restorations. The colour, translucency, and roughness parameters were evaluated, because all of these parameters are important in maintaining long-term aesthetics and the mechanical properties of the restoration. ${ }^{10,18}$

Previous studies ${ }^{31-33}$ on the colour of dental ceramics reported that colour change values below 3.7 are clinically acceptable. Therefore, the same limit was considered in this study.

The thermocycling process in oral cavity can affect the longevity of restorations. Using thermocycling parameters that can mimic oral environment in an in vitro condition could inspect the behaviour of restorations in a clinical setting. ${ }^{34}$ Therefore, in this study, 5000 cycles were used for ageing the specimens; this corresponds to an ageing duration of six months. ${ }^{35}$

One of the limitations of this study was that the ageing was conducted for a short duration (5000 cycles). Moreover, the thickness of the LDS material was kept constant.

In the future, the effects of different thicknesses and glazing procedures (paste, spray, and powder-liquid glaze) on the roughness, optical and mechanical properties of LDS materials can be evaluated after long-term ageing. In addition, the topography of LDS materials treated with different glazing procedures can be investigated using scanning electron microscopy and atomic force microscopy.

\section{CONCLUSIONS}

At the end of short-term ageing, although the type of surface treatment affected the colour and translucency values of the LDS restorations $(\mathrm{p}=.001)$, it did not affect the surface roughness change (after-before) values.

The ES and EP groups showed clinically acceptable colour change values $(\Delta \mathrm{E}<3.7)$, whereas the colour change values in the EL group were clinically unacceptable $(\Delta \mathrm{E} \geq 3.7)$.

The ES and EP processes should be preferred for the glaze treatment of LDS specimens when 
their colour and translucency change values are evaluated simultaneously.

When dentists select a material for glazing monolithic LDS specimens, they should consider the effects of this material on optical properties and surface roughness of the LDS specimens.

\section{ACKNOWLEDGEMENTS}

The authors thank Erman Toktay (statistician) for performing the statistical analysis of this study.

\section{CONFLICTS OF INTEREST}

None.

\section{Farklı Glaze İşlemlerinin Lityum Disilikat Seramiklerin Optik Özellik ve Pürü̈lülük Üzerindeki Etkileri}

\section{$\ddot{O} Z$}

Amaç: Farkll glaze işlemlerinin lityum disilikat seramiklerin (LDS) renk, translüsensi ve pürüzlülük üzerindeki etkisinin klsa dönem yaşlandırma sonunda incelenmesidir. Gereç ve Yöntemler: On sekiz LDS örnek (kalınlık: 0,6 mm) yapılan glaze işlemine göre ü̧ gruba (pasta (EP), sprey (ES), toz-likit glaze (EL)) ayrlld ( $n=6)$. Glaze firtnlamaları sonrası tüm örnekler termal olarak yaşlandırıldı (5000 devir). Yaşlandırma öncesi ve sonrasl örneklerin renk, translüsensi ve pürüzlülük değerleri ölçüldü. Yaşlandırma öncesi ve sonrası translüsensi ve pürüzlülük verileri tek yönlü varyans analizi (ANOVA) ile analiz edildi ve Wilcoxon işaretli sıralar testi ile karşılaş̧tırldd. Renk, translüsensi ve pürüzlülük değişim verileri tek yönlü ANOVA ile analiz edildi ve aralarındaki kolerasyonlar Spearman kolerasyon analizi ile analiz edildi $(p=, 05)$.

Bulgular: EL grubu en yüksek ve klinik olarak kabul edilemez renk değişim değeri göstermiştir ( $p \leq 005)$. Yaşlandırma öncesi ve sonrasi, EL grubu diğer gruplardan daha yüksek translüsensi değeri göstermiştir $(p<, 001)$ ve EL ve EP gruplarl, ES grubundan daha yüksek pürüzlülük değerleri göstermiştir ( $p \leq 001)$. Wilcoxon işaretli siralar test sonuçları göstermiş̧tir ki, EL grubunun başlangıç ve sonuç translüsensi değerleri arasinda anlaml fark $(p=, 028)$ gözlenir iken, her bir grubun başlangıç ve sonuç pürüzlülük değerleri arasında anlamlı bir farklllik bulunamamıştır. Sadece EL grubunda renk ve translüsensi değişim değerleri arasinda anlaml bir kolerasyon bulunmuştur $(r=0,943$, p=,005). Sonuçlar: Kısa dönem yaşlandırma sonrasinda, LDS seramiğin renk ve translüsensi değişsimleri değerlendirildiğinde, ES ve EP işlemleri glaze için tercih edilebilir. Diş hekimleri LDS seramiklerin glaze işlemi için materyal (EP, EL, ES) seçeceklerinde, bu materyalin LDS seramiklerin optik özellik ve yüzey pürüzlülüğ̈̈ üzerindeki etkisini göz önünde bulundurmalddrlar. Anahtar Kelimeler: Lityum disilikat, renk, yüzey özellikleri.

\section{REFERENCES}

1. Batson ER, Cooper LF, Duqum I, Mendonça G. Clinical outcomes of three different crown systems with CAD/CAM technology. J Prosthet Dent 2014; 112:770-777.

2. Ng J, Ruse D, Wyatt C. A comparison of the marginal fit of crowns fabricated with digital and conventional methods. J Prosthet Dent 2014; 112:555560.

3. Kelly JR, Benetti P. Ceramic materials in dentistry: historical evolution and current practice. Aust Dent $\mathbf{J}$ 2011; 56:84-96.

4. Yu B, Ahn JS, Lee YK. Measurement of translucency of tooth enamel and dentin. Acta Odontol Scand 2009; 67:57-64.

5. Giordano R. Materials for chairside $\mathrm{CAD} / \mathrm{CAM}-$ produced restorations. J Am Dent Assoc 2006; 137:1421.

6. Pieger S, Salman A, Bidra AS. Clinical outcomes of lithium disilicate single crowns and partial fixed dental prostheses: A systematic review. J Prosthet Dent 2014; 112:22-30.

7. Niu E, Agustin M, Douglas RD. Color match of machinable lithium disilicate ceramics: effects of foundation restoration. J Prosthet Dent 2013; 110:501509.

8. Barizon KT, Bergeron C, Vargas MA, Qian F, Cobb DS, Gratton DG, Geraldeli S. Ceramic materials for porcelain veneers. Part I: Correlation between translucency parameters and contrast ratio. J Prosthet Dent 2013; 110:397-401.

9. Spink LS, Rungruanganut P, Megremis S, Kelly JR. Comparison of an absolute and surrogate measure of relative translucency in dental ceramics. Dent Mater 2013; 29:702-707.

10. de Oliveira AL, Botta AC, Campos JÁ, Garcia PP. Effects of immersion media and repolishing on color stability and superficial morphology of nanofilled composite resin. Microsc Microanal 2014; 20:12341239.

11. Erdemir U, Yildiz E, Eren MM. Effects of sports drinks on color stability of nanofilled and microhybrid composites after long-term immersion. J Dent 2012; 40 Suppl 2:55-63.

12. Lund PS, Piotrowski TJ. Color changes of porcelain surface colorants resulting from firing. Int $\mathrm{J}$ Prosthodont 1992; 5:22-27. 
13. Kim IJ, Lee YK, Lim BS, Kim CW. Effect of surface topography on the color of dental porcelain. J Mater Sci Mater Med 2003; 14:405-409.

14. Wang H, Xiong F, Zhenhua L. Influence of varied surface texture of dentin porcelain on optical properties of porcelain specimens. J Prosthet Dent 2011; 105:242248.

15. Gönülol N, Yilmaz F. The effects of finishing and polishing techniques on surface roughness and color stability of nanocomposites. J Dent 2012; 40 Suppl 2:64-70.

16. Niu E, Agustin M, Douglas RD. Color match of machinable lithium disilicate ceramics: Effects of cement color and thickness. J Prosthet Dent 2014; 111:42-50.

17. Heffernan MJ, Aquilino SA, Diaz-Arnold AM, Haselton DR, Stanford CM, Vargas MA. Relative translucency of six all-ceramic systems. Part I: core materials. J Prosthet Dent 2002; 88:4-9.

18. Flury S, Peutzfeldt A, Lussi A. Influence of surface roughness on mechanical properties of two computeraided design/computer-aided manufacturing (CAD/CAM) ceramic materials. Oper Dent 2012; 37:617-624.

19. Alp G, Subasi MG, Johnston WM, Yilmaz B. Effect of surface treatments and coffee thermocycling on the color and translucency of CAD-CAM monolithic glass-ceramic. J Prosthet Dent 2018; 120:263-268.

20. Mota EG, Smidt LN, Fracasso LM, Burnett LH Jr, Spohr AM. The effect of milling and postmilling procedures on the surface roughness of CAD/CAM materials. J Esthet Restor Dent 2017; 29:450-458.

21. Basso GR, Kodama AB, Pimentel AH, Kaizer MR, Bona AD, Moraes RR, Boscato N. Masking Colored Substrates Using Monolithic and Bilayer CAD-CAM Ceramic Structures. Oper Dent 2017; 42:387-395.

22. Harada K, Raigrodski AJ, Chung KH, Flinn BD, Dogan S, Mancl LA. A comparative evaluation of the translucency of zirconias and lithium disilicate for monolithic restorations. J Prosthet Dent 2016; 116:257263.

23. Gunal B, Ulusoy MM. Optical properties of contemporary monolithic CAD-CAM restorative materials at different thicknesses. J Esthet Restor Dent 2018; 30:434-441.

24. Subaşı MG, Alp G, Johnston WM, Yilmaz B. Effect of thickness on optical properties of monolithic CAD-CAM ceramics. J Dent 2018; 71:38-42.
25. Acar O, Yilmaz B, Altintas SH, Chandrasekaran I, Johnston WM. Color stainability of CAD/CAM and nanocomposite resin materials. J Prosthet Dent 2016; 115:71-75.

26. Vichi A, Fonzar RF, Goracci C, Carrabba M, Ferrari M. Effect of Finishing and Polishing on Roughness and Gloss of Lithium Disilicate and Lithium Silicate Zirconia Reinforced Glass Ceramic for CAD/CAM Systems. Oper Dent 2018; 43:90-100.

27. Yuan JC, Barão VAR, Wee AG, Alfaro MF, Afshari FS, Sukotjo C. Effect of brushing and thermocycling on the shade and surface roughness of CAD-CAM ceramic restorations. J Prosthet Dent 2018; 119:1000-1006.

28. Gürdal I, Atay A, Eichberger M, Cal E, Üsümez A, Stawarczyk B. Color change of CAD-CAM materials and composite resin cements after thermocycling. J Prosthet Dent 2018; 120:546-552.

29. Kim HK, Kim SH, Lee JB, Han JS, Yeo IS, Ha SR. Effect of the amount of thickness reduction on color and translucency of dental monolithic zirconia ceramics. J Adv Prosthodont 2016; 8:37-42.

30. Jurišić S, Jurišić G, Zlatarić DK. In Vitro Evaluation and Comparison of the Translucency of Two Different All-Ceramic Systems. Acta Stomatol Croat 2015; 49:195-203.

31. Bayindir F, Ozbayram O. Effect of number of firings on the color and translucency of ceramic core materials with veneer ceramic of different thicknesses. J Prosthet Dent 2018; 119:152-158.

32. Gonuldas F, Yilmaz K, Ozturk C. The effect of repeated firings on the color change and surface roughness of dental ceramics. J Adv Prosthodont 2014; 6:309-316.

33. Yilmaz K, Gonuldas F, Ozturk C. The effect of repeated firings on the color change of dental ceramics using different glazing methods. J Adv Prosthodont 2014; 6:427-433.

34. Morresi AL, D’Amario M, Capogreco M, Gatto R, Marzo G, D'Arcangelo C, Monaco A. Thermal cycling for restorative materials: does a standardized protocol exist in laboratory testing? A literature review. J Mech Behav Biomed Mater 2014; 29:295-308.

35. Gale MS, Darvell BW. Thermal cycling procedures for laboratory testing of dental restorations. J Dent 1999; 27:89-99. 